\title{
Phytoremediation of Petroleum-Contaminated Soils Around Isfahan Oil Refinery (Iran) by Sorghum and Barley
}

\author{
FARIDA IRAJY ASIABADI ${ }^{1}$, SEYED AHMAD MIRBAGHER ${ }^{2 *}$, \\ PAYAM NAJAFI $^{3}$ and FARAMARZ MOATAR ${ }^{4}$
}

\author{
${ }^{1} \mathrm{Ph}$. D Student Environmental Science, Faculty of Environment and Energy, \\ Science and Research Branch, Islamic Azad University, Tehran, Iran. \\ ${ }^{2}$ Department of Environmental Engineering, Faculty of Environment and Energy, \\ Science and Research Branch, Islamic Azad University, Tehran, Iran. \\ ${ }^{3}$ Department of Water Engineering, Faculty of Agriculture and Natural Resources, \\ Khorasgan Branch, Islamic Azad University, Isfahan, Iran. \\ ${ }^{4}$ Department of Environmetal Engineering, Faculty of Environment and Energy, \\ Science and Research Branch, Islamic Azad University, Tehran, Iran.
}

http://dx.doi.org/10.12944/CWE.9.1.10

(Received: January 30, 2014; Accepted: February 24, 2014)

\begin{abstract}
Petroleum compounds are one of the most frequently encountered pollutants in soils adjacent to oil refineries. Phytoremediation, where feasible, has become a cost-effective alternative to physicochemical methods of soil remediation. In this study, sorghum (Sorghum bicolor) and barley (Hordeum vulgare) were selected for phytoremediation and the diminution in the concentration of oil-based contaminants was measured during a 90-day period. Contaminated and control treatments were compared in terms of root and shoot dry weight. Comparisons revealed reductions of about $22 \%$ and $30 \%$ in root dry matter and $51 \%$ and $42 \%$ in shoot dry matter of sorghum and barley in contaminated soil, respectively. The control and planted soils were significantly different in total and oil-degrading bacterial counts. Moreover, the concentration of total petroleum hydrocarbons decreased by $52 \%-64 \%$ in 90 days. Since planting the contaminated soil with sorghum and barley resulted in an improvement of $30 \%$ compared to unplanted contaminated soil, the two plants were highly efficient in removing petroleum from oil-contaminated soils. Therefore, despite the necessity of further studies to enhance the efficacy of phytoremediation by assessing the appropriateness of various plant species, some genotypes like sorghum and barley were found suitable choices for phytoremediation of the investigated petroleum-contaminated soil.
\end{abstract}

Key words: Phytoremediation, Total Petroleum Hydrocarbons, Oil-Degrading Bacteria, Barley, Sorghum.

\section{INTRODUCTION}

Environmental contamination following the use of various pollutants by humans has caused critical environmental problems throughout the world. In Iran, for instance, oil-contaminated soils and waters around oil fields and refineries have turned into major concerns. Oil-based contaminants in soil can threaten human and animal health by either entering the food chain or leaching into groundwater resources (Khan, 2005). The perception of existing environmental problems has led to numerous efforts to clean the environment.
Soil may be decontaminated through chemical, physical, and biological methods. While the first two approaches are costly and hence appropriate for highly polluted soils, biological methods are inexpensive and efficient in removing oil contamination from soil (Leahy and Colwell, 1990).

Phytoremediation is a relatively new, economical, effective, and environment-friendly biological soil decontamination method (Newman and Reynolds, 2005). It combines plant and microbial activity to degrade, transfer, deactivate, and reduce the mobility of soil and groundwater 
contaminants (Cunningham et al., 1997). The use of solar energy in phytoremediation significantly decreases soil decontamination costs (Luepromchai et al., 2007). Several studies have suggested the efficacy of various plants in eliminating different soil contaminants, particularly oil derivatives. In a study to decontaminate crude oil-polluted desert soils, Diab (2008) reported oil degradation rate as $62.4 \%, 19.9 \%$, and $17.6 \%$ using Vicia faba, Zea mays, and Triticum aestivum, respectively. Zhang et al.(2010) found 127 days of phytoremediation using Pharbitis nil L. to mitigate the concentration of oil derivatives by $27.7 \%-67.4 \%$ (vs. $10.2 \%-35.6 \%$ in the control soil). In another research, Lu et al. (2010) stated that 50 days after sowing Bidens maximowicziana, the mean reduction in pyrene concentration was $28 \%$ more in treated soil compared to the control soil.

Phytoremediation requires prudent selection of resistant, preferably native plants with the greatest possible germination, growth, expansion, and root surface area (Adam and Duncan, 2002). The selected plants will also need to be congruent with soil conditions in the target area and have the potential for complete development in the presence of contamination. Accordingly, laboratory and greenhouse studies to compare the germination and growth of different plants in contaminated soils and to evaluate their effects on concentrations of pollutants are essential to help select the most suitable plants at farm level.Considering previous studies on oil contamination and the properties of the target soil, we selected Sorghum bicolor and Hordeum vulgare (hereafter referred to as sorghum and barley) for phytoremediation of oil-contaminated soils around Isfahan Oil Refinery (Isfahan, Iran).

\section{MATERIALS AND METHODS}

\section{Soil Sampling}

After acquiring permissions from the Environment Department of Isfahan Oil Refinery, lands close to the refinery's Sulfur Recovery Unit and nearby uncontaminated soils were sampled at eight stations whose coordinates were recorded using a global positioning system (GPS) device. Samples were obtained from $0-30 \mathrm{~cm}$ depth of soil and transferred to the laboratory in closed glass containers covered with ice packs.

While previous Iranian research on oilcontaminated soils has mainly added contamination to unpolluted soil, during the phytoremediation, such soils will exhibit totally different behavior compared to soil from oilcontaminated lands (Huang et al., 2005). Therefore, the current study sampled a contaminated area to ensure accurate results and clarify the existing conditions.

Measuring Physical and Chemical Properties of Soil The efficiency of processes to decrease the concentration of petroleum hydrocarbons in soil depends widely on physical and chemical properties of soil (Tang et al., 2012). After passing air-dried soil samples through a 2-mm sieve, a number of tests were conducted in triplicate to assess the texture (through hydrometry), $\mathrm{pH}$ (Thomas, 1996), electrical conductivity (Rhoades, 1996), organic matter (Nelson and Sommers, 1982), total nitrogen (Bremner and Mulvaney, 1982), available phosphorus (Olsen and Sommers, 1982), and available potassium (Page et al., 1982) of the samples. Finally, $\mathrm{CaCO} 3$ equivalent of the samples was determined through neutralizing with hydrogen chloride and back titration with sodium hydroxide (Allison and Moodie, 1965) (Table 1).

Table 1:Physical and Chemical Properties of Soil Samples

\begin{tabular}{lcc}
\hline $\begin{array}{l}\text { Characteristic } \\
\text { Texture }\end{array}$ & $\begin{array}{c}\text { Control } \\
\text { Soil Sandy } \\
\text { clay loam }\end{array}$ & $\begin{array}{c}\text { Contaminated } \\
\text { Soil Sandy } \\
\text { clay loam }\end{array}$ \\
\hline $\mathrm{pH}(1: 2.5)$ & 7.9 & 7.3 \\
$\begin{array}{l}\text { Electrical } \\
\text { conductivity (ds } / \mathrm{m})\end{array}$ & 1.7 & 3.2 \\
$\begin{array}{l}\text { Organic matter }(\%) \\
\text { Total nitrogen }(\%)\end{array}$ & 0.8 & 4.7 \\
$\begin{array}{l}\text { CaCO } \\
\text { equivalent }(\%)\end{array}$ & 32 & 0.90 \\
$\begin{array}{l}\text { Available- } \\
\text { phosphorus }(\mathrm{mg} / \mathrm{kg})\end{array}$ & 42 & 25 \\
$\begin{array}{l}\text { Available- } \\
\text { potassium }(\mathrm{mg} / \mathrm{kg})\end{array}$ & 19 & 74 \\
\hline
\end{tabular}


Evaluating the Concentration of Total Petroleum Hydrocarbons (TPHs)

In order to measure the concentrations of polycyclic aromatic hydrocarbons (PAHs) and TPHs in the soil, Soxhlet extraction using 1:1 (v/v) nhexane/dichloromethane solvent $(150 \mathrm{ml})$ mixture was first performed for 24 hours (Christopher et al., 1988). Afterward, the extracted compounds were placed in a rotary evaporator which evaporated the solvent under vacuum and condensed the samples. The samples were then purified using column chromatography (with silica gel and alumina as absorbent). The concentration of PAHs was evaluated with gas chromatography (US Environmental Protection Agency, 1984). According to the measurements (mean petroleum hydrocarbon concentration $=75,000 \mathrm{mg} / \mathrm{kg}$ ), soil samples from areas adjacent to the oil refinery were extremely contaminated (Table 2).

\section{Phytoremediation}

Contaminated and control soil samples were poured in triplicate into pots with a diameter and height of 20 and $50 \mathrm{~cm}$, respectively. Sorghum and barley seeds were then sowed at $1-2 \mathrm{~cm}$ depth. Unplanted treatments were also present to exclude the effects of environmental factors on reduction of oil-based contaminants.

Phytoremediation was performed during August-October 2012. Minimum and maximum greenhouse temperature was recorded every day and the plants were watered based on their daily

Table 2: Concentrations of the Measured Polycyclic Aromatic Hydrocarbons (PAHs) and Total Petroleum Hydrocarbons (TPHs) in Contaminated Soil

\begin{tabular}{clc}
\hline Hydrocarbons & $\begin{array}{c}\text { Concentration } \\
\text { (mg/kg) }\end{array}$ \\
\hline \multirow{2}{*}{ PAHs } & Naphthalene & 45 \\
& Phenantherene & 34 \\
& Anthracene & 6 \\
& Fluoranthene & 29 \\
& Pyrene & 16 \\
& Benzo[k]fluoranthene & 0.4 \\
TPHs & Benzo[a]pyrene & 0.7 \\
& & 75000 \\
\hline
\end{tabular}

status while water loss from the bottom of the pots was prevented.

Due to limited access to the root tissue, the harvest was carried out at the final stages of the study. Ninety days after sowing, rhizosphere and non-rhizosphere soil samples were collected to determine the total petroleum hydrocarbon content, total bacterial count, and number of oil-degrading bacteria. The roots and shoots of the plants were also weighed after being separated and dried in an oven at $80^{\circ} \mathrm{C}$ for 48 hours.

\section{Counting Total and Oil-Degrading Bacteria}

In order to determine the total number of bacteria in the soil, one gram soil was added to a test tube containing $9 \mathrm{ml}$ of $0.9 \%$ sterile sodium chloride solution and shaken thoroughly. A serial dilution $\left(10^{-1}-10^{-8}\right)$ was subsequently made and transferred to the culture medium. The culture was incubated at $28^{\circ} \mathrm{C}$ for 48 hours and the formed colonies were counted (Soleimani, et al., 2010). The same method was used to count oil-degrading bacteria.This time, however, the culture consisted of $990 \mathrm{ml}$ sterile agar solution and $\mathrm{CaCl}_{2-} \mathrm{H}_{2} \mathrm{O}(0.02$ g), $\quad \mathrm{FeCl}_{3}(0.05 \mathrm{~g}), \mathrm{MgSO}_{4-} 7 \mathrm{H}_{2} \mathrm{O}(0.2 \mathrm{~g})$, $\mathrm{K}_{2} \mathrm{HPO}_{4}(1.00 \mathrm{~g}), \mathrm{NH}_{4} \mathrm{NO}_{3}(1.00 \mathrm{~g}), \mathrm{KH}_{2} \mathrm{PO}_{4}(1.00 \mathrm{~g})$ $(\mathrm{pH}=7)$. It also contained $10 \mathrm{ml}$ of filtered sterile oil (fresh crude oil from Isfahan Oil Refinery) as the sole source of carbon. The mean number of bacteria at $25,50,75$, and $100 \mathrm{~cm}$ depths of the soil column and various dilutions was reported as colonyforming unit (CFU) per gram of soil.

\section{Statistical Analyses}

We used a full factorial experiment design with two factors (plant and soil having three and two levels, respectively)and three replications. All statistical analyses were performed in SPSS for Windows 17.0 (SPSS Inc., Chicago, IL, USA) at a significance level of 0.05 . The obtained mean values were compared using Duncan's test.

\section{RESULTS AND DISCUSSION}

\section{Results of Dry Matter Yield}

Statistical analyses revealed the type of plant and soil to have affected dry matter yield. Dry weight comparisons between contaminated and control treatments showed that in petroleum 
hydrocarbon-containing soil, sorghum and barley had reductions of about $22 \%$ and $30 \%$ in root dry matter and $51 \%$ and $42 \%$ in shoot dry matter, respectively.

Sorghum had the highest shoot dry weight in the control treatment. Barleyandsorghum had the least shoot and root dry weights in the contaminated treatment (Figure 1). Consistent with our findings, Cheema et al. (2009) suggested that the root and shoot dry matter of Festuca arundinacea decreased (by $29.7 \%$ and $53.5 \%$, respectively) 65 days after being sowed in soil contaminated with pyrene and phenantherene. Reduced plant growth and dry matter yield in oil-contaminated soil can be justified by the existence of petroleum hydrocarbons along with suppressed root growth and decreased uptake of water and nutrients (Chaineau, et al., 1997).

\section{TPHs in Soil}

Compared to unplanted treatments, sorghum and barley could lower TPHs in contaminated soil by $35 \%$ and $23 \%$, respectively (Figure 2). This statistically significant difference can indicate the efficacy of both plants in remediating petroleum-based contaminants. On the other hand, as Figure 2 shows, sorghum and barley reduced total petroleum hydrocarbons by about $64 \%$ and $52 \%$ compared to their baseline levels $(P<0.05)$.

Vegetation enhances the degradation of organic soil contaminants through not only improving physical properties of soil but also increasing the bioavailability of hydrocarbons, root exudates, growth stimulation, and the activity of oildegrading bacteria. Research on phytoremediation of oil-contaminated soil has thus been extensive.

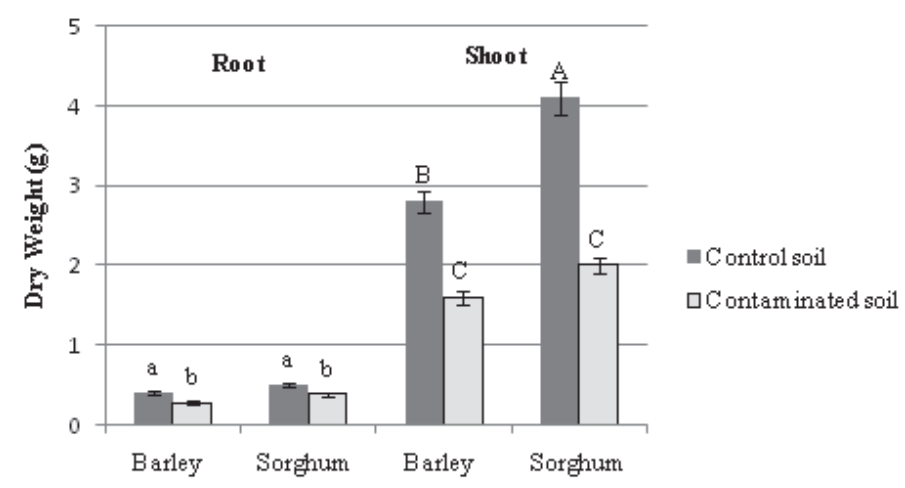

Fig. 1: Shoot and root dry weight ofsorghum and barley after three months of growth in petroleumcontaminated and control soils[Different letters (capital letters for shoot and small letters forroot) represent significant differences according toDuncan's test $(P<0.05)$. Error bars arestandard deviations

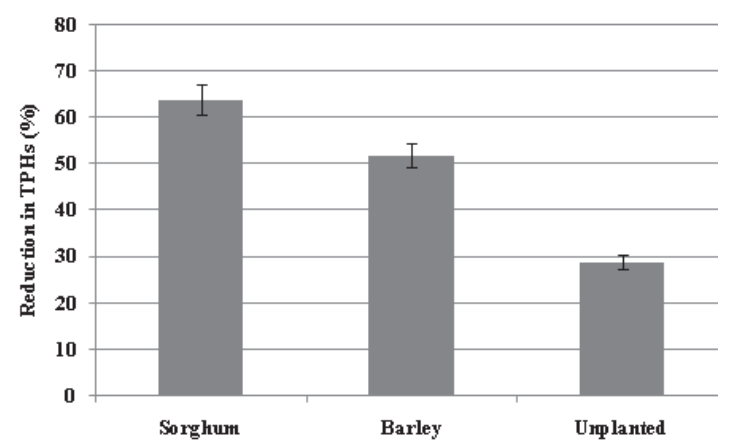

Fig. 2: Effects of plant species on the elimination of total petroleum hydrocarbons (TPHs) compared to the control (unplanted) treatment
Liste and Alexander (2000) examined the efficacy of nine plant species in reducing pyrene contamination. After eight weeks, they calculated pyrene reduction as $74 \%$ in planted soil and $40 \%$ in unplanted soil. Hutchinson et al. (2001) suggested Cynodon dactylon and Festuca to decrease the concentration of petroleum hydrocarbons by $68 \%$ and $62 \%$, respectively. Peng et al. (2009) concluded that over a 127-day period, phytoremediation by Mirabilis Jalapa L. could eliminate $41 \%-63 \%$ of TPHs. Meanwhile, the rate was as low as $19 \%-37 \%$ in unplanted soil.

The mentioned degradation of contaminants seems to be caused by soil microbial 
activity in the rhizosphere. Kaimi et al. (2006) found the concentration of oil to be $55 \%$ lower in the rhizosphere of ray grass than in non-rhizosphere soil. Moreover, the number of aerobic bacteria was higher in the rhizosphere and had a positive correlation with root growth. Agamuthu et al. (2010) concluded that the bacteria in the rhizosphere of Jatropha curcas use and consequently degrade a great deal of hydrocarbons. Similarly, according to our findings, the concentration of TPHs in rhizosphere was less than that in non-rhizosphere soils (Figure 3 ).

Total Bacterial Count and Number of Biodegrading Bacteria in Soil

Planted and unplanted treatments had a significant difference in total bacterial count and number of biodegrading bacteria. Previous studies have reported increased soil microorganisms in the presence of plant species (Li et al., 2002; Cheema et al., 2009; Lu et al., 2010). Comparison of planted samples revealed that total bacterial count was always higher in contaminated soils than in control soils. In addition, the maximum number of biodegrading bacteria and total bacterial count were seen in the rhizosphere of sorghum and barley (Figures 4 and 5). Research has indicated a negative correlation between remaining TPHs and the number of microorganisms in soil. In fact, the greatest reduction of oil contamination is detected in the rhizosphere where there are large populations of soil microorganisms (Tang et al., 2012; Tejeda et al., 2012). Degradation of petroleum hydrocarbons in the soil is facilitated by enhancedbiodegradation

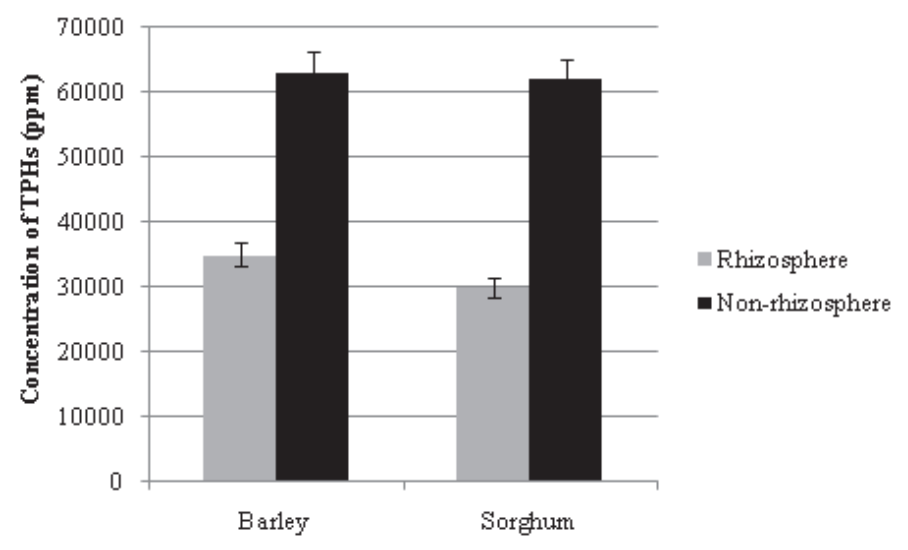

Fig. 3: Comparison between reductions in total petroleum hydrocarbons (TPHs) in rhizosphere and non-rhizosphere soils planted with barley and sorghum

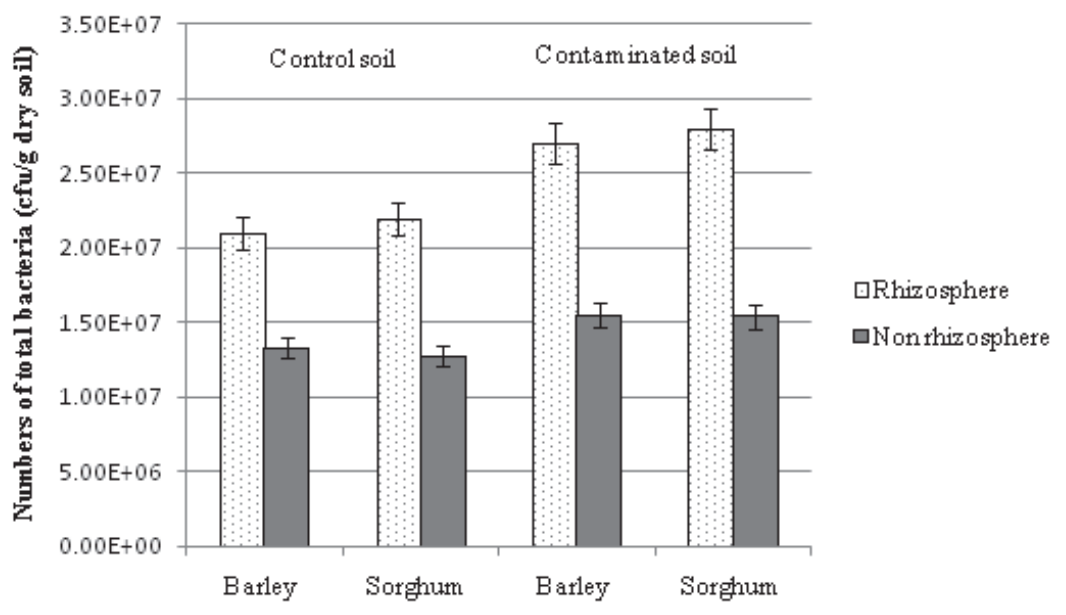

Fig. 4: Comparison of total bacterial count in rhizosphere and non-rhizosphere of contaminated and control soils containing sorghum and barley 


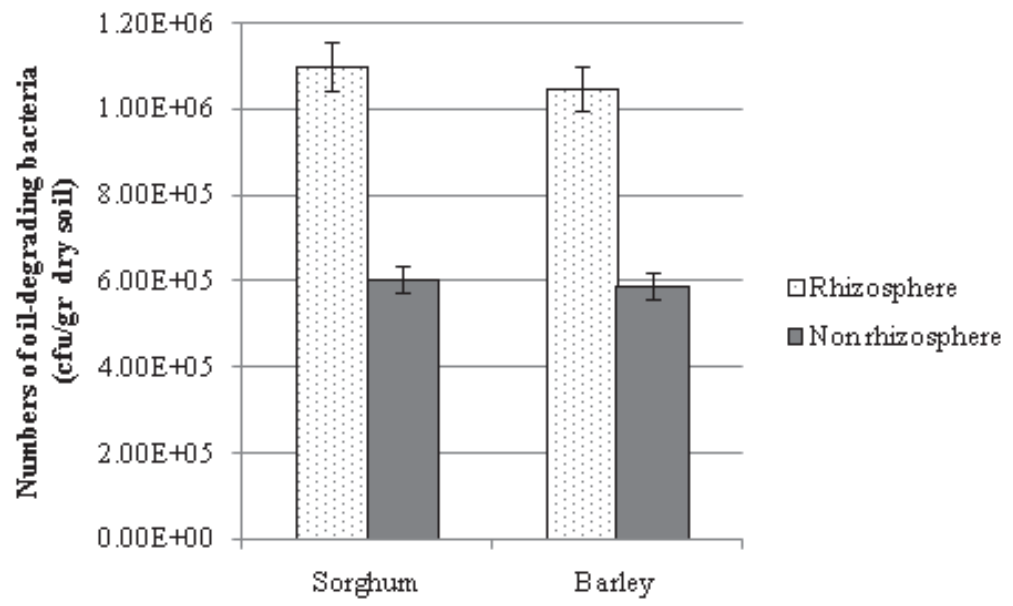

Fig. 5: Comparison between total numbers of oil-degrading bacteria in rhizosphere and nonrhizosphere of contaminated soils containing sorghum and barley

of petroleum-based contaminants, increased number and diversity of oil-degrading bacteria, promotion of chemical secretions, and stimulation of plants in the rhizosphere (Tejeda et al., 2012).

\section{CONCLUSION}

The current study used sorghum and barley to remediate petroleum hydrocarboncontaminated soil from lands near Isfahan Oil Refinery. The results showed that the two plants were capable of tolerating high concentrations of petroleum hydrocarbons and toxic materials in soil, i.e. although their growth was decelerated in contaminated soil, it was not inhibited.

Sorghum and barley could successfully decrease the concentration of petroleum hydrocarbons in soil by 52\%-64\% (30\% higher than the rates in unplanted soil). Reductions in contaminants of unplanted soil might be attributed to leaching, adsorption, oxidation in exposure to light, evaporation, and biodegradation. In vegetated soils, all the mentioned processes are accompanied with the plants' ability to uptake and degrade contamination. Besides, soil microbial population is increased in the presence of plant species as the rhizosphere provides optimal conditions for proliferation of bacteria. The significant difference between planted and unplanted soils asserts the favorable role of the selected plants in eliminating petroleum hydrocarbons from soil. This is of critical importance since even very low concentrations of organic contaminants can threaten human health. Hence, sorghum and barley are recommended for elimination of petroleum hydrocarbons and improving soil conditions in areas close to Isfahan Oil Refinery.

\section{ACKNOWLEDGEMENT}

We appreciate the managing director, Mr. Nazem (the head of the research and development unit), and all personnel, especially Mr. Hedayati, of Isfahan Oil Refinery.

\section{REFERENCES}

1. Adam, G. and Duncan, $\mathrm{H}$. Influence of Diesel Fuel on Seed Germination. Environmental Pollution, 120: 363-370 (2002).

2. Agamuthu, P., Abioye, O.P. and Abdul Aziz, A. Phytoremediation of Soil Contaminated with Used Lubricating Oil Using Jatropha
Curcas. Journal of Hazardous Materials, 179 (1-3): 891-894 (2010).

3. Allison,L.E. andMoodie, C.D. Carbonate, In: Methods of Soil Analysis, Black, C.A., Evans, D.D., White, J.L., Ensminger, L.E. and Clark, F.E. (Eds). American Society of Agronomy. 
Madison Wisconsin USA, 1379-1400 (1965).

4. Bremner, J.M. and Mulvaney, C.S. NitrogenTotal, In: Methods of Soil Chemical Analysis. Page, A.L., Miller, R.H. and Keeney, D.R. (Eds). American Society of Agronomy. Madison Wisconsin USA, 595-624 (1982).

5. Chaineau, C.H., Morel, J.L. and Oudot, J. Phytotoxicity and Plant Uptake of Fuel Oil Hydrocarbons. Journal of Environmental Quality, 26: 1478-1483 (1997).

6. Cheema, S.A., Khan, M.I., Tang, X., Zhang, C., Shen, C., Malik, Z., Ali, S., Yang, J., Shen, K., Chen, $X$. andChen, $Y$. Enhancement of Phenanthrene and Pyrene Degradation in Rhizosphere of Tall Fescue (Festuca Arundinacea). Journal of Hazardous Materials, 166: 1226-1231 (2009).

7. Christopher, S., Hein, P., Marsden, J. and Shurleff, A.S. Evaluation of Methods 3540 (Soxhlet) and 3550 (Sonication) for Evaluation of Appendix IX Analyses from Solid Samples, S-CUBED. Report for EPA Contract 68-03-33-75. Work Assignment No.03. Document No, SSS-R-88-9436 (1988).

8. Cunningham, S.D., Shann, J.R., Crowley, D.E. and Anderson, T.A. Phytoremediation of Contaminated Water and Soil. In Kruger, E.L., Anderson, T.A. and Coats, J.R. (Eds). Phytoremediation of Soil and WaterContaminants. ACS Symposium Series No 664. American Chemical Society. Washington, DC (1997).

9. Diab, E.A. Phytoremediation of Oil Contaminated Desert Soil Using The Rhizosphere Effects. Global Journal of Environmental Research, 2: 66-73 (2008).

10. Huang, X.D., El-Alawi, Y., Gurska, J., Glick, B.R. and Greenberg, B.M. A Multi-Process Phytoremediation System for Decontamination of Persistent Total Petroleum Hydrocarbons (TPHs) from Soils. Microchemical Journal, 81: 139-147 (2005).

11. Hutchinson, S.L., Banks, M.K. and Schwab, A.P. Bioremediation and Biodegradation, Phytoremediation of Aged Petroleum Sludge: Effect of Inorganic Fertilizer. Environ. Qual, 30: 395-403 (2001).

12. Kaimi, E., Mukaidani, T., Miyoshi, S. and Tamaki, M. Ryegrass Enhancement of
Biodegradation in Diesel-Contaminated Soil. Environmental and Experimental Botany, 55(1-2): 110-119 (2006).

13. Khan, A.G. Role of Soil Microbes in The Rhizospheres of Plants Growing on Trace Metal Contaminated Soils in Phytoremediation. Journal of Trace Elements in Medicine and Biology, 18: 355-364 (2005).

14. Leahy, J.G. and Colwell, R.R. Microbial Degradation of Hydrocarbons in the Environment. Microbial. Rev, 54: 305-315 (1990).

15. Li, C.H., Ma, B.L. and Zhang, T.O. Soil Bulk Density Effects on Soil Microbial Population and Enzyme Activities During The Growth of Maize (Zea Mays) Planted in Large Pots Under Field Exposure. J. Plant. Sci, 82: 147154 (2002).

16. Liste, H.H. and Alexander, M. Accumulation of Phenanthrene and Pyrene in Rhizosphere Soil. Chemosphere, 40(1): 1114 (2000).

17. Lu, S., Teng, Y., Wang, J. and Sun, Z. Enhancement of Pyrene Removed from Contaminated Soils by Bidens Maximowicziana. Chemosphere, 81: 645650 (2010).

18. Luepromchai, E., Lertthamrongsak, W., Pinphanichakarn, P., Thaniyavarn, S., Pattaragulwanit, $\mathrm{K}$. and Juntongjin, $\mathrm{K}$. Biodegradation of PAHs in PetroleumContaminated Soil Using Tamarind Leaves as Microbial Inoculums. Songklanakarin Journal of Science and Technology, 29(2): 515- 527 (2007).

19. Nelson, D.W. and Sommer, L.E. Total Carbon, Organic Carbon and Organic Matter. In: Methods of Soil Analysis. Page, A.L., Miller, R.H. and Keeney, D.R. (Eds). American Society of Agronomy. Madison Wisconsin USA, 539-576 (1982).

20. Newman, L.A. andReynolds, C.M. Bacteria and Phytoremediation: New Uses for Endophytic Bacteria in Plants. Trends in Biotechnology, 23(1): 6-8 (2005).

21. Olsen, S.R. andSommers, L.E. Phosphorus, In: Methods of Soil Analysis. Page, A.L., Miller, R.H., Keeney, D.R., Baker, D.E., Ellis, R. and Rhoades, J.D. (Eds). American Society of Agronomy. Madison Wisconsin 
USA, 403-430 (1982).

22. Page, A.L., Miller, R.H. and Keeney D.R. Methods of Soil Analysis. American Society of Agronomy. Madison Wisconsin USA, 1159 (1982).

23. Peng, S., Zhou, Q., Cai, Z. and Zhang, Z. Phytoremediation of Petroleum Contaminated Soils by Mirabilis JalapaL. in aGreenhouse Plot Experiment. Journal of Hazardous Materials, 168(2-3): 1490-1496 (2009).

24. Rhoades, J.D. Salinity: Electrical Conductivity and Total Dissolved Solids. In: Methods of Soil Analysis. Page, A.L., Miller, R.H. and Keeny, D.R. (Eds). American Society of Agronomy. Madison Wisconsin USA, 417435 (1996).

25. Soleimani, M., Afyuni, M., Hajabbasi, M.A., Nourbakhsh, F., Sabzalian, M.R. and Christensen, J.H. Phytoremediation of an Aged Petroleum Contaminated Soil Using Endophyte Infected and Non-Infected Grasses. Chemosphere, 81: 1084-1090 (2010).
26. Tang, J., Lu, X., Sun, Q. and Zhu, W. Aging Effect of Petroleum Hydrocarbons in Soil Under Different Attenuation Conditions. Agriculture, Ecosystems and Environment, 149:109-117 (2012).

27. Tejeda-Agredanoa, M.C., Gallego, S., Vila, J., Grifoll, M., Ortega-Calvo, J.J. and Cantos, M. Influence of the Sunflower Rhizosphere on The Biodegradation of PAHs in Soil. Soil Biology and Biochemistry, xxx: 1-11 (2012).

28. Thomas, G.W. Soil pH and Soil Acidity. In: Methods of Soil Analysis. Sparks, D.L. (Eds). American Society of Agronomy. Madison Wisconsin USA, 475-490 (1996).

29. US EPA. Interalaboratory Comparison Stunt: Methods for Volatile and Semi-Volatile Compounds. Environmental Monitoring Systems Laboratory. Office of Research and Development. Las Vegas, NV, EPA. 600/484- 027 (1984).

30. Zhang, Z., Zhou, Q., Peng, S. and Cai, Z. Remediation of Petroleum Contaminated Soils by Joint Action ofPharbitis nil L. and its Microbial Community. Science of the Total Environment, 408: 5600-5605 (2010). 